\title{
Tramas, tranças e cestarias
}

\section{José Antônio Gomes de \\ SOUZA}

\section{Resumo}

Em tramas, tranças e cestarias procuro desenvolver um diálogo entre as artes plásticas e o artesanato. Recorro à técnica da trançagem e a diversidade de materiais como: couro de boi, plásticos, borrachas e papéis. Entrelaçando esses elementos em telas convencionais pintadas em outros tempos. Às vezes são trabalhos antigos com mais de dez anos, suportes de outras propostas e que agora, recorto e faço filetes. Um exercício de paciência em busca de manter constante e atual o passado, uma forma de trazer o passado ao presente e recorrer ao passado para refazer o presente. O resultado são imagens ricas em efeitos de óptica, surpreendente pelas tramas criadas, que descaracterizam o antes visível a favor de uma nova imagem, em uma outra situação. Uso mais o estilete que o pincel, como forma de destruir para reconstruir, de fazer um novo trabalho, agregando outras cores e outros materiais, afinal são outras emoções. Respeito e desrespeito o passado, o já feito e visto. Em alguns desenhos, uso ferros de construção, linhas trespassadas geometricamente como queria Mondrian, numa natureza com dois ritmos fundamentais - o vertical e o horizontal.

Palavras-chave: Pintura, artesanato, desenho. 